\title{
Neuronal Hypertrophy in Rat Colon Caused by Protein Deficiency
}

\author{
Marcelo Biondaro Gois ${ }^{*}$, Catchia Hermes-Uliana ${ }^{2}$, Kátia Biagio Fontes ${ }^{3}$, Eliane Muniz ${ }^{1}$, Eduardo Jose \\ de Almeida Araújo ${ }^{4}$, Marcilio Hubner de Miranda-Neto ${ }^{1}$ and Débora de Mello Gonçales Sant'Ana ${ }^{1}$
}

\author{
${ }^{1}$ State University of Maringa, Department of Morphological Sciences, Maringa, Parana, Brazil \\ ${ }^{2}$ University of Federal do Mato Grosso do Sul, Campus de Coxim, Maringa, Parana, Brazil \\ ${ }^{3}$ University of Paranaense, Department of Biology, Maringa, Parana, Brazil \\ ${ }^{4}$ State University of Londrina, Department of Histology, Maringa, Parana, Brazil
}

\begin{abstract}
The effects of different protein levels associated with vitamin deprivation have been evaluated on tissues of high and low cell renewal. This study aimed to investigate the effects of available diet with $4 \%$ protein content associated with the maintenance of vitamin levels on the morphology of NADPH dp+ myenteric neurons of rats descending colon. Sixteen animals were randomly distributed into two groups, one that was fed with chow with $26 \%$ protein content (CG), and the other was fed with a $4 \%$ protein content diet (EG) during 12 weeks. Total preparations were used to make the myenteric plexus neurons of the descending colon evident when submitted to NADPH-diaphorase. The cellular bodies and nucleus of 300 neurons from each animal was measured. The diet with $4 \%$ protein and maintenance of vitamin and mineral content, similar to the ones found in normal protein diets, causes metabolic alterations that result in body weight loss. The myenteric neurons of the descending colon have non-significant reduction in the nucleus size whereas the cytoplasm presents a significant increase of the area. The importance of vitamin maintenance and the increase of the neuronal area are discussed as a possible compensating mechanism to keep neurotransmitter synthesis.
\end{abstract}

Keywords: Enteric nervous system; Protein malnutrition; NADPH-diaphorase; Large intestine; Myenteric plexus.

Corresponding author: Marcelo Biondaro Gois, Department of Morphological Sciences, State University of Maringa, street: Jose Barao Neto, number 526; Maringa, Parana, Brazil, Zip code: 87080-030, Tel: +55 44 9958-0392; E-mail: marcelobiondaro@gmail.com

Citation: Gois, M.B., et al. Neuronal Hypertrophy in Rat Colon Caused by Protein Deficiency (2014) J Food Nutr Sci 1(1): 31-34.

\section{Received Date: Nov 18, $2014 \quad$ Accepted Date: Nov 25, $2014 \quad$ Published Date: Nov 28, 2014}

\section{Introduction}

The enteric nervous system (ENS) consists of two main plexuses, the myeteric (Auerbach's) plexus that is located between the longitudinal and circular layers of the muscular layer, and the submucosa (Meissner's) plexus, located in the tela sub$\operatorname{mucosa}^{[1,2]}$.

The main function of the myenteric plexus is the reflexive control of the intestinal motility. To perform its motor functions, the myenteric neurons can be subdivided into two large subpopulations: cholinergic and nitrergic with contractile and relaxing functions of the smooth muscle, respectively ${ }^{[3]}$. The nitrergic neurons have neuromediator nitric acid $(\mathrm{NO})^{[4]}$ that is a neuroprotector, antioxidant and growth stimulant ${ }^{[5,6]}$

The myenteric plexus has morphological and functional characteristics that vary according to the different segments of the digestive tube in humans as well as in animals ${ }^{[1,7]}$, and it can have alterations in several experimental models like diabetes ${ }^{[8,9]}$, Chagas disease $\mathrm{e}^{[10,11]}$, toxoplasma infection ${ }^{[12,13]}$ and protein malnutrition $^{[14-16]}$.

Protein deficiency causes decrease in the total neural population $^{[17-19]}$ or increase in its density ${ }^{[20,21]}$. Myenteric neu- ronal subpopulations like cholinergic neurons ${ }^{[22]}$, positive NADH-diaphorase $\mathrm{e}^{[19,16]}$ and nitrergic neurons ${ }^{[14,15]}$ are also affected by malnutrition.

Positive NADPH-diaphorase neurons are specially important to characterize nitrergic neuron population with inhibiting motor activity ${ }^{[23,24]}$. Previous studies have shown that these neurons can be affected by protein malnutrition and, therefore, this study aimed to evaluate the effects of severe protein malnutrition on the morphometry of myenteric nitrergic neurons of rats descending colon.

\section{Material and Methods}

All the experimental procedures were previously approved by the Ethics Committee for Research on Animals Experimentation (CEPEEA) of Universidade Paranaense.

Sixteen male, 90-day-old, Wistar rats (Rattus norvegicus) (body mass of $313.92 \pm 9.79 \mathrm{~g}$ ) were separated into a control group ( $\mathrm{CG} ; \mathrm{n}=8)$, fed normally, and an experimental group (EG; $\mathrm{n}=8$ ), submitted to protein malnutrition. They were kept in individual cages in an animal house with controlled temperature and humidity and a 12-hour light/dark cycle.

Copy rights: (C2014 Gois, M.B. This is an Open access article distributed under the terms of Creative Commons Attribution 4.0 International License. 
CG was fed NUVILAB ${ }^{\circledR}$ added with $26 \%$ of protein, and the EG was fed a diet prepared with $4 \%$ of protein through the addition of corn starch and keep the vitamin and mineral balance according to the description by Araujo et al. ${ }^{[25]}$. Both groups were given chow and water ad libitum for 90 days. After this period, the rats from both groups were anesthetized and euthanized with Acepran $(1.26 \mathrm{~mL} / \mathrm{Kg})$, Ketamine-10\% (1.26 mL/ $\mathrm{Kg})$, Xylazine- $2 \%(0,42 \mathrm{~mL} / \mathrm{Kg})$ and Atropine- $1 \%(0.22 \mathrm{~mL} /$ $\mathrm{Kg}$ ) intramuscularly ${ }^{[26]}$.

Descending colon was hystochemically submitted to NADPH-d to make it evident. A segment of each animal was removed, washed in phosphate buffer solution (PBS pH 7.4), immersed and fixated in paraphormaldehyde at $4 \%{ }^{1}$, prepared in $\mathrm{pH} 7.40 .1 \mathrm{M}$ for 30 minutes; next, they were immersed in a solution of Triton $\mathrm{X}-100^{\circledR} 0.3 \%$ dissolved in PBS $\mathrm{pH} 7.40 .1 \mathrm{M}$ for 10 minutes and posteriorly washed 10 times (10 minutes each) in $\mathrm{PBS} \mathrm{pH} 7.40 .01 \mathrm{M}$. Then, to make neuronal $\beta-\mathrm{NADPH}^{+}$evident, they were immersed in an incubation medium containing a solution of 0.05 de Nitroblue Tetrazolium NBT ${ }^{2}$ in $200 \mathrm{~mL}$ of tris$\mathrm{HCl}$ buffer solution; $0.1 \mathrm{~g}$ of $\beta-\mathrm{NADPH}^{3}$ and $0.6 \mathrm{~mL}$ of Triton $\mathrm{X}-100$. The segments were washed in PBS $0.01 \mathrm{M} \mathrm{pH} 7.4$ (three times, 5 minutes each), and the reaction interruption occurred by adding paraformaldehyde at $4 \%$ in PBS $0.01 \mathrm{M} \mathrm{pH} 7.4^{[24]}$.

For the morphometric analysis, the area of the cell and nucleus body of 100 neurons of each region of the intestinal circumference (mesocholic, intermediate and antimesocholic) of all animals from both groups were measured through the images obtained by a 40x lens microscope with a video camera coupled to a computer with an image analysis software ${ }^{4}$. The cytoplasm area was calculated from the differences in these areas. The ratio between the nucleus area and the cell body area, as well as their correlation, was calculated. The neurons were classified in 50 $\mu \mathrm{m}^{2}$ intervals for the cell body.

Initially, data was submitted to D'Agostino-Pearson's test or Shapiro-Wilk's test to verify distribution. Data for normal distribution are presented as means \pm standard deviation. In this case, to compare the groups, Student's t test was utilized for the independent samples. Data with free distribution are presented as means and percentages (25:75), therefore, the comparison between the groups was done by Mann-Whitney's test. The correlation analysis was verified with Sperman's non-parametric test. In all statistical tests, $p$ values lower than 0.05 were considered significant. All the analyses were performed using BioEstat 5.0 software ${ }^{[27]}$.

\section{Results}

The body mass in the beginning of the experiment was $311.83 \pm 11.27 \mathrm{~g}$ in $\mathrm{CG}$ and $316 \pm 9.99 \mathrm{~g}$ in $\mathrm{EG}(\mathrm{p}>0.05)$. In the end, the body weight was $403.43 \pm 11.23 \mathrm{~g}$ in $\mathrm{CG}$ and $246.50 \pm$ $18.34 \mathrm{~g}$ in $\mathrm{EG},(\mathrm{p}<0.05)$.

There was an increase in the cell body area, cytoplasm area, cell body/nucleus area ratio without alteration of the nucleus in EG (Table1).
Table 1: Means and percentage (P25:P75) of the cell body, cytoplasm area, nucleus area, and nucleus/cell body area ratio of positive NADPH-diaphorase myenteric neurons of descending colon of normally fed rats, control group (CG) and submitted to protein malnutrition, experimental group (EG).

\begin{tabular}{|l|l|l|}
\hline Measurement & CG & EG \\
\hline Cell body $\left(\mu \mathrm{m}^{2}\right)$ & $181.30(144.00: 218.72)$ & $193.71(159.22: 232.14)^{*}$ \\
\hline Cytoplasm $\left(\mu \mathrm{m}^{2}\right)$ & $140.13(108.67: 173.36)$ & $156.25(124.50: 192.07)^{*}$ \\
\hline Nucleus $\left(\mu \mathrm{m}^{2}\right)$ & $39.00(28.66: 48.52)$ & $36.86(28.66: 45.99)$ \\
\hline Ratio & $0.21(0.17: 0.26)$ & $0.19(0.15: 0.23)^{*}$ \\
\hline
\end{tabular}

Values marked with an asterisk $(*)$ in the same line presented significant difference $(\mathrm{p}<0,0001)$.

The correlation degree between the body cell area, nucleus area and cytoplasm area of positive NADHP-d myenteric neurons $\left(\mathrm{NADPH}-\mathrm{d}^{+}\right)$of the descending colon is shown in Figure 1 for CG and in Figure 2 for EG.

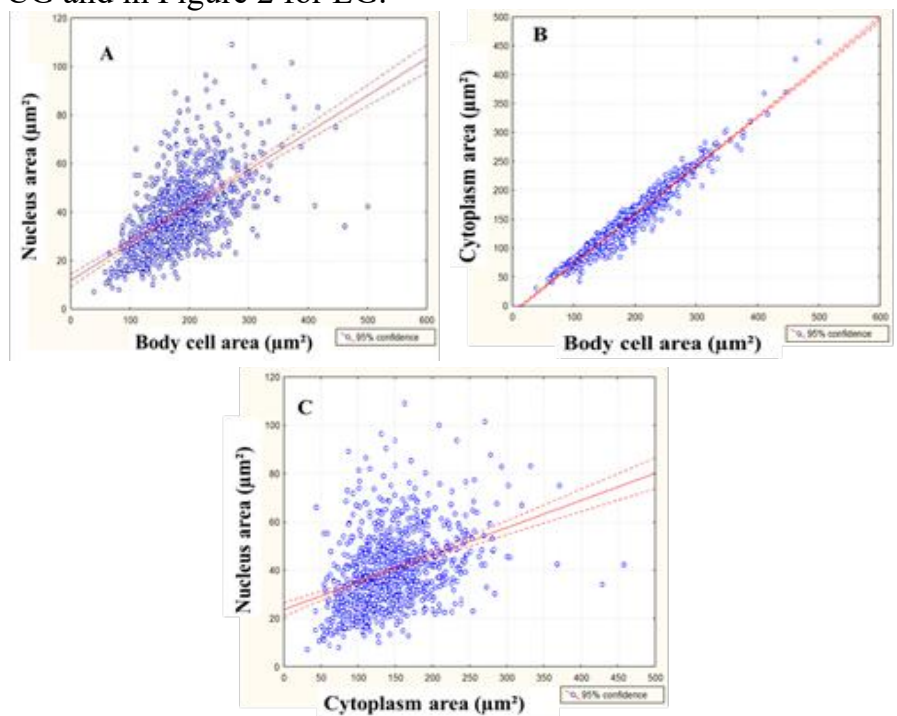

Figure 1: Dispersion diagram of the correlation between the cell body area and the nucleus area $(\mathrm{A}, \mathrm{r}=0.59, \mathrm{p}<0.05)$, body cell area and cytoplasm area $(\mathrm{B}, \mathrm{r}=0.97$, $\mathrm{p}<0.05)$ and cytoplasmareaandnucleusarea $(\mathrm{C}, \mathrm{r}=0.38, \mathrm{p}<0.05)$ ofNADPH-diaphorase myenteric neurons of descending colon of normally fed rats (Control Group).
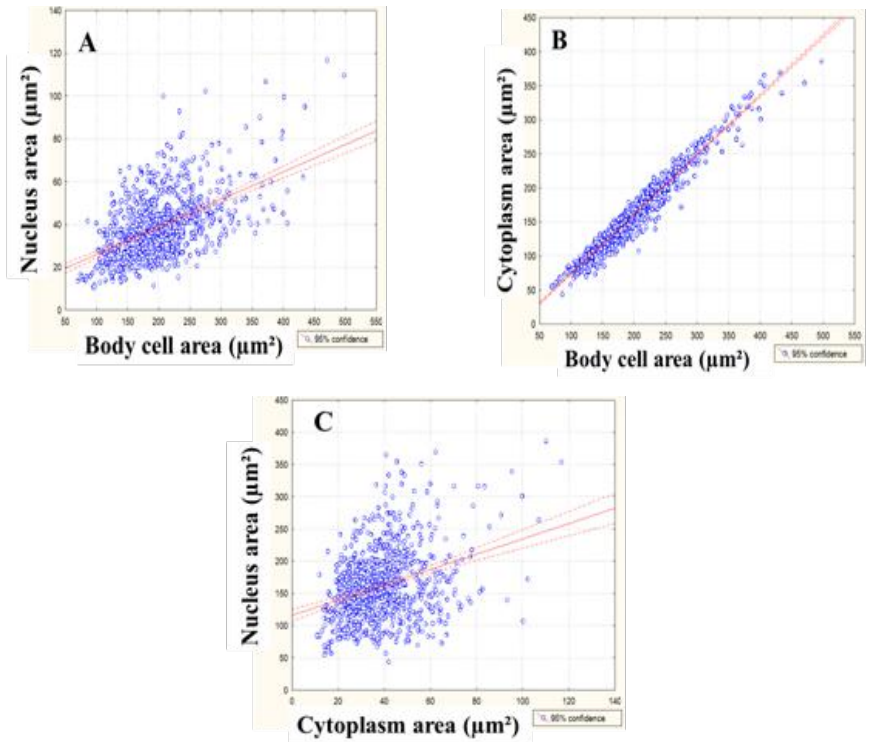

Figure 2: Dispersion diagram of the correlation between the cell body area and the nucleus area $(\mathrm{A}, \mathrm{r}=0.53, \mathrm{p}<0.05)$, body cell area and cytoplasm area $(\mathrm{B}, \mathrm{r}$ $=0.97, \mathrm{p}<0.05)$ and cytoplasm area and nucleus area $(\mathrm{C}, \mathrm{r}=0.32, \mathrm{p}<0.05)$ of NADPH-diaphorase myenteric neurons of descending colon of rats submitted to protein malnutrition (Experimental Group).

\footnotetext{
${ }^{2}$ Nitroblue Tetrazolium Gibolbrl, New York, USA

${ }^{3}$ Sigma, Steinheim, Germany

${ }^{4}$ Motic Imagem Plus versão 2.0
} 
The number of distributed neurons in classes, according to the body cell area, as well as the body cell area and nucleus area ratio, is show in Figure 3.

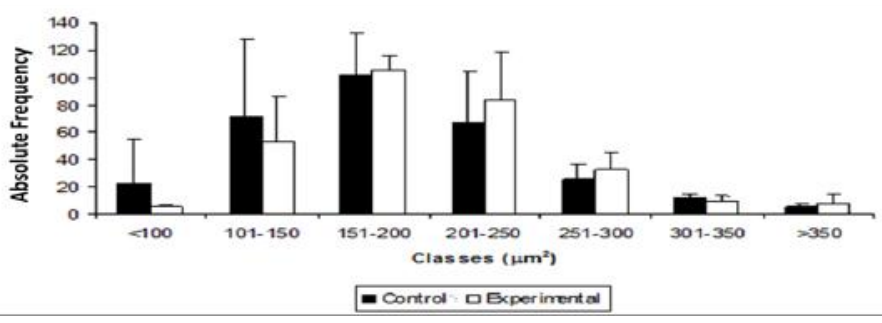

Figure 3: Distribution of myenteric neurons of descending colon of control rats (control group) stained by NADPH-diaphorase and submitted to protein malnutrition (experimental group) distributed according to the classes of the cell body area. The values do not present significant difference $\mathrm{p}>0.05$.

The protein malnutrition increased the cell body area due to the augmentation of the cytoplasm volume without the corresponding increase in the nucleus volume.

\section{Discussion}

The protein content of $4 \%$ in the chow through the addition of cornstarch was insufficient to allow the animals' body mass development. The body mass of EG animals was $38.89 \%$ lower than the $\mathrm{CG}$, besides not gaining weight EG rats had a $22.24 \%$ body mass decrease after 12 weeks of treatment. Reduction of the body mass was not found in rats that were fed with $8 \%$ protein content diets ${ }^{[18]}$; on the other hand, rats that received diets with less than $5 \%$ protein content, similarly to the results found in this study, lost weight ${ }^{[14]}$. This shows that when the protein ingestion is very low, the organism has difficulty to transform carbohydrates into fat reserve, possibly due to the lack of aminoacids for the synthesis of structural and functional proteins like enzymes that are related to the conversion of glycides into lipids. On the other hand, the reduction in weight indicates the use of fat stores in the processes of energy production and possible insufficiency of protein for maintenance of muscle mass. Araujo et al. ${ }^{[14]}$ points out that a hypoprotein diet for a long period triggers a mechanism that allows adaptation when there is low protein availability in order to preserve the nervous tissue. In this study, an increase of the body cell area of NADPH-dp neurons in EG was observed and it may be due to the increase of the cytoplasm volume, once the nucleus had non-significant reduction of its size.

The increase of the cytoplasm area can be relate to different mechanisms: (1) due to neuronal loss related to diet with $4 \%$ proteins ${ }^{[14]}$, the remaining neurons, possibly increase the volume of the cell body as part of an adaptive mechanism to compensate the lost neurons through an increase in their cytoplasm system for protein synthesis, assuring the maintenance of the target tissue. Zanoni et al. ${ }^{[28]}$ report that the neuronal hypertrophy in diabetic rats is associated with the attempt to keep the neurotransmitter production in favor of the lost neuronal population; (2) would the augmentation of the neuronal body be the initial stage of apoptosis? The protein restriction can induce metabolic failure and result in organelle damages, mainly in mitochondria. Mitochondrial lesion activates the intrinsic pathway to apoptosis by means of caspases. Thus, it is possible to infer that the lower protein content in the diet caused the deprivation of neuronal growth factors (NGF) and other essential substances that regulate the bioenergetics flow, resulting in the activation of pro-apoptotic cytoplasm proteins of Bcl-2 family ${ }^{[29]}$. The increase of the cytoplasm volume associated with the $5.6 \%$ reduction ( $p>0.0001$ ) of the nucleus area corroborate this hypothesis because this morphological aspect is common in cells in the beginning of apoptosis. With the evolution of apoptosis, the nucleus becomes disproportionately small (pycnotic nucleus) and with intensely condensed chromatin. This can be visualized by staining techniques that use acid/basic differentiation ${ }^{[30]}$; (3) would hypertrophy observed in this study be due to an attempt to keep the NADPH-d enzyme expression? Similarly to this study, a previous study with the same animals was associated to the myenteric neuronal death ${ }^{[14]}$, indicating a probable increase in the activity of the nitric oxide synthesis (NOS) and in the production of nitric oxide (NO) in the remaining neurons.

Our results suggest that the vitamin and mineral maintenance utilized in this study prevented the atrophy of NA$\mathrm{DPH}-\mathrm{dp}^{+}$neurons; in addition, it augmented the cytoplasm volume which can be a consequence of the increase of the synthesis of the remaining neurons to compensate possible neuronal losses and keep the neurotransmitter levels compatible to the necessities of the target tissue. The intensification of neuronal damage by the association of the vitamin deficiency with the protein deficiency was evident in a previous study ${ }^{[15]}$ carried out with rats that were fed with $4 \%$ protein content diets and reduced vitamin levels, resulting in neuronal loss and atrophy of remaining nitrergic neurons of the myenteric plexus of the descending colon. In the cecum, Muniz et al. ${ }^{[31]}$ verified that there was a reduction in the area of the body cell and nucleus of NADPH-d neurons of animals submitted to a hypoproteic diet (4\%) for 90 days; however, with the preservation of the neuronal population, this atrophy occurs by neuronal modulation when there is a lower amino acid availability for protein synthesis. These findings are divergent from the ones found in this study, and suggest that there may be different adaptive mechanisms to protein deficiency, among them the maintenance of neuron amount associated with the reduction of the cellular body volume, and consequent reduction of the neuron synthesis machinery. Another possibility is the reduction of the amount of NADPH $-\mathrm{dp}^{+}$neurons, as verified in the descending colon of rats in a previous study ${ }^{[14]}$ with the same diet utilized in this study. In that case, the increase of the cellular body volume, found in the present study, could be a consequence of the increment of the remaining neuron synthesis. The neurons made evident by NADPH-d hystochemistry represent a neuronal subpopulation involved with the nitrergic pathway that has inhibiting potential to the intestinal smooth muscle contraction $^{[24,25]}$. Therefore, hypertrophy, verified in this study, allows us to infer that there was an alteration in NADPH-d enzyme expression, resulting in a neurotransmitter unbalance of descending colon and that this can be related to the diarrhea observed along the experimental period ${ }^{[14]}$.

In this experiment, it was observed that the positive correlation between the body cell and the nucleus of nitrergic neurons was 59\% in $\mathrm{CG}$ and $53 \%$ in EG, suggesting that the growth and/or reduction of the nucleus size did not follow the cell body size. That was not found when the correlation between the body and cytoplasm was observed (97\%), indicating that the cell body of myenteric neurons can follow (as a cause or a consequence) the alterations in the cytoplasm of the same neurons. 
When analyzing the distribution of the cell body area, it was observed that there was no difference between the analyzed classes. Despite the homogenous distribution, the neurons of both groups were mainly from 151 to $200 \mu \mathrm{m}^{2}$. Regarding the cell body area, the neuron incidence between the different classes did not present a significant difference between the groups; there was a predominance of neurons whose nucleus occupies from 16 to $20 \%$ of the cell body in both groups, indicating that malnutrition kept distribution uniformity of the studied classes, even though it caused hypertrophy.

To sum up, the provision of the diet with reduced protein content to $4 \%$ through the addition of starch associated with the maintenance of the vitamin and mineral levels, similar to the one found in normal protein diets, causes the metabolic alterations that result in body weight loss that is possibly related to the lack of amino acids for the synthesis of enzymes related to the utilization of carbohydrates as an energy source and the conversion of fat reserves. In NADPH- $\mathrm{dp}^{+}$neurons of the descending colon there is a non-significant reduction of the nucleus size while the cytoplasm increases its area significantly.

\section{References}

1. Furness, J.B., Costa, M. The enteric nervous system. (1987) Edinburgy: Churchill Livingstone pp: 340.

2. Furness, J.B. The enteric nervous system and neurogastroenterology. (2012) Nat Rev Gastroenterol Hepatol 9(5): 286-294.

3. Phillips, R.J., Kieffer, E.J., Powley, T.L. Aging of the myenteric plexus: neuronal loss is specific to cholinergic neurons. (2003) Auton neurosci 106(2): 69-83.

4. Grundy, D.,Al-Chaer, E.D.,Aziz, Q., etal.Fundamental of neurogastroenterology: basic science. (2006) Gastroenterology 130(5): 1391-1411. 5. Toumi, F., Neulist, M., Denis, M.G., et al. MAP kinase-dependent and PKA-independent pathways. (2004) Biochemical and Biophisical Research Communications 317(1): 187-191.

6. Alves, E.P., Alves, A.M., Pereira, R.V., et al. Immunohistochemical study of vasoactive intestinal peptide (VIP) enteric neurons in diabetic rats supplemented with L-glutamine. (2010) Nutr Neurosci 13(1): 43-51. 7. Gabella, G. The number of neurons in the small intestine of mice, Guinea-pigs and sheep. (1987) Neuroscience 22(2): 737-752.

8. Furlan, M.M., Molinari, S.L., Miranda-Neto, M.H. Morphoquantitative effects of acute diabetes on the myenteric neurons of the proximal colon of adult rats. (2002) Arq Neuro-psiquiatr 60(3): 576-581.

9. Surendran, S., Kondapaka, S.B. Altered expression of neuronal nitric oxide synthase in the duodenum longitudinal muscle-myenteric plexus of obesity induced diabetes mouse: implications on enteric neurodegeneration. (2005) Biochem biophys Res Commun 338(2): 919-922.

10. Ribeiro-Jr, U., Safatle-Ribeiro, A.V., Habr-Gama, A. et al. Análise das alterações do óxido nítrico em pacientes com megacólon chagásico. (1998) Rev Bras Colo-Proct 18(1): 52-57.

11. Guillén-Pernía, B., Lugo-Yarbuh, A., Moreno, E. Dilatación del tracto digestivo de ratones infectados com Trypanosoma cruzi.( 2001) Invest clín 42(3): 195-210.

12. Hermes-Uliana, C., Pereira-Severi, L.S., Luerdes, R.B., et al. Chronic infection with Toxoplasma gondii causes myenteric neuroplasticity of the jejunum in rats. (2011) Auton Neurosci 160(1-2): 3-8.

13. Sant'Ana, D.M., Gois, M.B., Zanoni, J.N., et al. Intraepithelial lymphocytes, goblet cells and VIP-IR submucosal neurons of jejunum rats infected with Toxoplasma gondii. (2012) Inter J Exp Pathol 93(4) :279-286.
14. Araujo, A.E.J., Sant'Ana, G.D.M., Molinari, S.L., et al. Quantitative study of the myenteric plexus of the descending colon of young rats subjected to intense protein deficiency. (2006) Int. J. Morphol24(4): 591-597. 15. Araujo, E.J.A., Hermes, C., Miranda Neto, M.H. et al. Atrophy of the nitrergic myenteric neurons in the descending colon rats submitted to protein and vitamin deficiency. (2009) Int J Morphol 27(3): 939-945. 16. Moreira, N.M., Muniz, E., Hermes-Uliana, C. et al. Atrofia de neurônios do plexo mientérico do íleo de ratos submetidos à intensa carência de proteínas. (2012) Acta Scientiarum Biological Sciences 34(2): 207-212.

17. Sant'Ana, D.M.G., Miranda Neto, M.H., Souza, R.R., et al. Morphological and quantitative study of the myenteric plexus of the ascending colon of rats subjected to proteic desnutrition. (1997) Arq Neuro-psiquiatr 55(4): 687-695.

18. Natali, M.R., Molinari, S.L., Valentini, L.C., et al. Morphoquantitative evaluation of the duodenal myenteric neuronal population in rats fed with hypoproteic ration. (2005) Biocell 29(1): 39-46.

19. Sant'Ana, D.M.G., Molinari, S.L., Araujo, E.J.A., et al. The effect of both protein and vitamin B complex deficiency on the morphoquantitative features of the myenteric plexus of the ascending colon of adult rats. (2006) Arq Cienc Vet Zool Unipar 9(2): 135-140.

20. Molinari, S.L., Fernandes, C.A., Oliveira, L.R., et al. NADH - diaphorase positive myenteric neurons of the aglandular region of the stomach of rats (Rattus norvegicus) subjected to desnutrition. (2002) Rev Chil Anat 20(1): 19-23.

21. Zanin, S.T.M., Molinari, S.L., Sant'Ana, D.M.G., et al. Neurônios $\mathrm{NADH}$-diaforase positivos do jejuno de ratos adultos (Rattus norvegicus) desnutridos. Aspectos quantitativos. (2003) Arq neuro-psiquiatr 61(3-A): 650-653.

22. Brandão, M.C.S., Angelis, R.C., De-Souza, R.R., et al. Effects of pre- and postnatal protein energy deprivation on the myenteric plexus of the small intestine: a morphometric study in weanling rats. (2003) Nutr res 23(2): 215-223.

23. Scherer-Singler, U., Vicent, S.R., Kimura, H., et al. Demonstration of a unique population of neurons with NADPH-diaphorase histochemistry. (1983) J Neurosci Methods 9(3): 229-234.

24. Young, H.M., Furness, J.B., Shuttleworth, C.W.R., et al. Co-localization of nitric oxide synthase immunoreactivity and NADPH diaphorase staining in neurons of the Guinea-pig intestine. (1992) Histochemistry 97(4): 375-378.

25. Araújo, E.J.A., Sant'Ana, D.M.G., Molinari, S.L., et al. Biometric and food consumption parameters of rats subjected to hypoproteic and hipercaloric diet. (2005) Arq Ciên Vet Zool Unipar 8(2): 131-138.

26. Pachaly, J.R. Anestesia of Wistar rats (Rattus norvegicus) with allometrically scaled doses of ketamine, xulazine, acepromazine and atropine-preliminary report. (2003) Arq Cien Zool Unipar 12: 195-201.

27. Ayres, M., Ayres, M.J.R., Ayres, D.L., et al. BioEstat: aplicações estatísticas nas áreas das Ciências Biológicas e Médicas. (2007) Sociedade Civil Mamirauá: Belém, MCT-CNPq.

28. Zanoni, J.N., Hernandes, L., Bazotte, R.B., et al. Terminal ileum submucous plexus: Study of the VIP-ergic neurons of diabetic rats treated with ascorbic acid. (2002) Arq Neuro-psiquiatr 60(1): 32-37.

29. Green, D.R., Kroemer, G. The pathophysiology of mitochondrial cell death. (2004) Science 305(5684): 626-629.

30. Danial, N.N., Korsmeyer, S.J. Cell Death: Critical Control Points. (2004) Cell 116(2): 205-219.

31. Muniz, E., Sant'Ana, D.M.G., Araújo, E.J.A. Morphometric and quantitative analysis of the neurons of the myenteric plexus of the cecum of rats submitted to intense lack of protein. (2007) Arq Ciên Vet Zool Unipar 10(2): 77-84. 